\title{
Discussion on Management and operation guarantee measures for tourist highway construction in Shanxi Province
}

\author{
Jianrong $\mathrm{Ma}^{1}$, Huan Liu ${ }^{1}$, Qiang Meng ${ }^{2}$ \\ ${ }^{1}$ Research Institute of Highway Ministry of Transport, Beijing, 100088, China \\ ${ }^{2}$ Road Hi-Tech Transportation Technology Group Co., Ltd. Beijing, 100088, China
}

\begin{abstract}
With the industrial economy in Shanxi Province showing the pressure of gear shifting and transformation and upgrading, the province's GDP growth has slowed down significantly. In sharp contrast to this, the tourism industry in Shanxi Province has maintained rapid growth, becoming a new bright spot in the transformation and development of Shanxi Province, and a new driving force for economic development. As one of the pillars of the development of the tourism industry, tourist roads have put forward new requirements for the construction scale, service quality, and operation management of tourist roads. Based on the status of the planning and demonstration construction of tourism roads in Shanxi Province, This paper analyses and discusses the management and management issues that are incomplete in the implementation process, involving too many procedures of management departments, insufficient funds, and unclear operation and profit models. Organizational management and operation guarantee measures for the whole province's tourist highways.
\end{abstract}

\section{Background}

With the development of China's tourism industry and the outbreak of self-driving tourism, the construction of tourist highways has also formed a climax nationwide, such as the National No. 1 Scenic Road, Chishui River Valley Bicycle Path, and Weihai Coastal Tourism Highway. Tourism transportation, tourism resources, travel agencies and tourist reception facilities considered four pillars of modern tourism. Therefore, that the development of tourism industry, highway transportation plays an essential auxiliary role. Highway transportation has the advantages of being flexible, fast, convenient, and direct. As the number of tourists continues to increase, the demand for highway transportation services continues to increase and increase. Therefore, the integrated development of highways and tourism can not only promote the transformation and development of transportation, promote the rapid development of regional economy and society, but also better meet the new needs of the public for a better life. In order to implement the requirements of the "Several Opinions on Promoting the Integrated Development of Transportation and Tourism" jointly issued by the six departments including the Ministry of Transport, the 2018 Shanxi Provincial Government Work Report proposes to build a strategic pillar industry for cultural tourism and forge the Yellow River, Great Wall and Tai Hang. At the same time, the Shanxi Provincial Government issued policies such as the "Opinions on Promoting the Reform and Development of Tourism" and "Implementation
Opinions on Further Promoting Tourism Investment and Consumption" in order to speed up the construction of tourism highways in the province, providing strong support.

\section{Problem analysis}

In recent years, as the tourism industry continues to grow in scale and the tourism economy become an important economic growth point in Shanxi province, the infrastructure for service tourism is constantly being improved. As a basic and leading industry, transportation provides the necessary support and support services for the development of tourism, and further ensures that the "stable growth, benefiting the people's livelihood, and restructuring" policies and measures are put in place. In order to build the tourist road network in the main area, Shanxi Province took the lead in constructing two experimental sections in Luliangkou and Linfen Qiankun Bay in 2018. The demonstration implementation shows that there is still a lack of conceptual understanding, technical measures, and organization in irregularities of the tourism road management. These problems are particularly prominent in poor planning, involving too many management departments, insufficient capital investment, unclear operation and profit models, and uncoordinated development with surrounding tourism resources. Tourism road construction is a platform for integrated development of transportation and tourism, which involves planning approval, land approval, capital investment, management interfaces of various departments, and later operation rights and 
responsibilities, etc., and it has a high degree of social relevance. Therefore, it is necessary to coordinate the top-level design to help remove barrier management Can restrict the development of tourism in the region. However, at present, a comprehensive tourism coordination mechanism is not formed in management, it is difficult to meet the needs of industrial development, and there are problems such as incomplete systems and rigid mechanisms. Secondly, the main body of the tourism market is not fully developed, the government and enterprises in the scenic spots are not distinguished, the endogenous driving force for development is insufficient, and the prospects for investment return are unknown. Whether it is the integration mechanism of tourism resources or the reform of the management system of tourism scenic spots, Shanxi Province has not yet carried out. Therefore, in view of this situation, based on the analysis of domestic successful cases, we explore the measures for the organization, management, and operation guarantee of tourist highway construction in Shanxi Province.

\section{Case analysis}

\subsection{Chishui river valley tourist highway}

The Chishui River Valley Tourist Highway is a typical successful case of "highway + tourism" integration. It is the nation's first full-service fast and slow comprehensive transportation corridor, consisting of 160 kilometres of mountain bike lanes and 154 kilometres of automobile lanes. A total of 12 post stations, 26 campgrounds, 23 observation decks and rest spots were set up along the entire line, driving the tourism industry economy along the line, and solving the employment and targeted poverty alleviation of the people along the line. The organization and management experience of this tourist highway construction is summarized as follows:

- Mechanism:"Municipal coordination, hierarchical responsibility, multi-party participation".

- Organization: Zunyi Transportation and Tourism Development Co., Ltd..

- $\quad$ Funding: Zunyi Municipal People's Government authorized the Transportation Bureau as the investor of the project to account for $40 \%$ of the shares, and the introduction of social capital accounted for $60 \%$ of the shares (PPP).

- System: "Administrative Measures for Chishui River Valley Tourist Highway in Zunyi City".

\subsection{Taizhou beautiful highway}

In 2016, the conceptual plan for the construction of Taizhou 's beautiful highway was officially released, requiring all counties (cities, districts) to promote the construction of "beautiful highways" in accordance with the characteristics of local planning, humanities, tourism, and industries, and reflect the landscape of the highway The beauty of the sea, the beauty of the sea and the sky, the beauty of the humanities, the beauty of leisure and the beauty of the city. In order to promote the construction in an all-round way, the determined organization and management policies are as follows:

- Mechanism: Establish multi-sector joint operations mechanism.

- Organization: Beautiful highway construction work leading group.

- Funding: Multi-party financing for construction.

- System: "Taizhou Beautiful Highway Construction Implementation Opinions" and "Taizhou Beautiful Highway Construction Assessment Methods".

\section{Organization management guarantee}

\subsection{Establish a specialized management agency}

Planning period. First of all, the provincial government should do a good job of policy guidance and management of tourist highways, and make top-level planning. Provincial Development and Reform Commissions, Provincial Land and Resources Department, Provincial Environmental Protection Department, Provincial Housing and Construction Department, Provincial Forestry Department, Provincial Tourism Bureau and other provincial departments will coordinate this system to work together to expedite early approvals, and the Provincial Land and Resources Department will implement the tourism highway Land use indicators for construction projects. Each city and county government should arrange special personnel to speed up the preliminary work to ensure that the project starts construction on time and completes the planning. Secondly, it is recommended to use "the leadership of the municipal government and the assistance of the Scenic Area Management Committee and the Transportation and Highway Department, the Municipal Government, the Municipal Development and Reform Commission, the Municipal Finance Bureau, the Municipal Land Bureau, the Municipal Environmental Protection Bureau, the Municipal Transportation Bureau, the Municipal Forestry Bureau, the Municipal Agricultural Bureau, The city's tourism and other administrative departments coordinated with each other's promotion mechanism, clarified the responsibilities of each department, and divided labor and cooperation. As soon as possible after the project is established, a leading group for the construction of tourism roads should be established. The main leader or deputy leader of the municipal government should be the team leader, and the relevant leaders of the Transportation Bureau (Tourism Bureau) and the Highway Bureau should be the deputy team leaders. The day-to-day office is responsible for the project's establishment, planning, design, and construction. At the same time, it adopts the contact conference system to coordinately solve the problems in the progress of the tourism highway demonstration project. At the same time, relying on the opportunity of new construction or expansion of national and provincial highways and rural roads, some of the scenic area 
resources are integrated, and the overall operation mechanism is planned.

Building period. Based on the Chishui River Valley tourist highway construction as a template, the transportation and tourism development limited company was established by the city. The legal representative is the leader of the municipal government. The original tourism highway construction leadership group was directly transferred to the board of directors, and several subsidiaries were responsible for it. Engineering construction, operation, leasing of tourist roads, agricultural product marketing, catering companies, etc.

Operation period. Group companies are authorized to carry out financing planning, establish cultural exchange platforms, investment cooperation platforms, and sports event platforms to introduce investment in tourism projects.

\subsection{Establish a scientific management mechanism}

The tourist highway is generally approved by the city segment and the main function part of the project feasibility study report, and the project proposal is no longer approved. The project feasibility study report was jointly reviewed by the Provincial Department of Transport and the Provincial Development and Reform Commission, the Department of Housing and Urban-Rural Development, and the Tourism Bureau and submitted for approval in accordance with the prescribed procedures. Tourism roads will be included in the provincial key construction project plan, and the land use index will be coordinated by the Provincial Department of Land and Resources. The Provincial Department of Forestry and the Environmental Protection Department study and guide the deployment of slow-moving systems in forest protection belts and wetlands in accordance with the needs of forest areas for transportation and tourism. The special examination and approval of planning, site selection, land use, sea use, and environmental impact assessment are under the guidance of the relevant provincial departments, and the municipal and municipal governments are responsible for the implementation. The examination and approval matters involving national ministries and commissions are coordinated and implemented by the relevant provincial departments.

\subsection{Promotion mechanism guarantee}

Provincial relevant departments should implement their tasks as soon as possible, and appropriately simplify the approval procedures for key projects, improve the efficiency of project approval, and promote the smooth implementation of projects. Each city must focus on the principle of territorial management, concentrate its efforts, integrate projects, and push forward with all its strength. Actively advance the preliminary work, mainly including project feasibility study, preliminary design, construction drawing design, land approval, environmental assessment, forest assessment, soil and water conservation, earthquake assessment, and land acquisition and demolition, etc., to lay the foundation for project construction. The three major sections of tourist highway construction will be included in the government's key work construction plan, and key arrangements will be made in the next three years. The tourist highway construction will be included in the provincial and county government's target assessment system as a provincial key project, and the construction of tourist highway will be promoted.

\subsection{Establishing an advisory committee mechanism}

The Advisory Committee is a non-profit volunteer organization that seeks to maintain and guarantee the construction of tourist roads by recruiting professionals, volunteers, tourism companies, and local residents in various industries, providing tourist road technology, information, events, and related news. Management and operations. The technical advisory committee is chaired by the head of the Municipal Communications Bureau. Professionals from various industries such as transportation, construction, soil and water, gardening, and economics are standing members, others are general members, and the Highway Bureau is the daily work organization for the specific implementation and management of tourism highways.

\section{Operational safeguards}

\subsection{Strengthen the construction and management of tourist roads}

Good-quality tourism highway products are inseparable from the high-quality maintenance management process. We must fully recognize the important role of maintenance in the development of tourism highways and actively explore the operation mechanism of tourism highway construction and maintenance management. Highway maintenance and management should adopt a combination of professional maintenance and mass maintenance; annual maintenance combined with seasonal maintenance; priority maintenance combined with graded maintenance to improve various situations and maintenance responsibility systems, and improve the quality of tourism highway services.

\subsection{Exploring the operating mechanism and profit model}

Improve the current policy, unblock the funding channels, establish a diversified and multi-channel tourism highway operation mechanism and profit model, establish an independent accounting and self-financing Shanxi Transportation Investment and Operation Company, and encourage participation in the construction and operation of tourism highways throughout the state.

Establish and improve the government-led, investment-financing model of multi-level funding for 
tourism highways, attract social capital, and raise funds for construction and maintenance through multiple channels. Through the cooperation model between the government and social capital, tourism roads, ancillary facilities and surrounding scenic spots (scenic spots) are packaged for overall operation and development, and the sustainable and healthy development of Shanxi's tourist roads is promoted.

The tourism highway project that directly generates traffic value to the scenic spot will be tested on a trial basis. Scenic areas or administrations with higher incomes use tourism income to subsidize tourism roads through nutrition protection funds, forming a virtuous circle with the construction of tourist roads.

\subsection{Increase publicity and promotion of tourism road tourism products}

Shaping and promoting the overall tourism brand of Shanxi Province, focusing on the independent innovation of the brand and the exclusivity of brand resources, occupying the brand's highlands, and competing for the brand image right and the right to speak. The province needs to strengthen the commercial operation and continuous management of brands, and improve the management and promotion mechanism of brands. Government-led, widely attracting participation from all walks of life, through marketing methods such as internet, advertising media, and marketing activities. After the overall brand has been recognized, specialized marketing is targeted at different target markets, in order to adapt to the promotion of the value demands of market segments Ways to find breakthrough points, create bright spots, attract the attention of important media, and promote the broad recognition of tourism brands.

\section{References}

1. State Council. (2017). Opinions on Supporting Further Deepening Reform in Shanxi Province to Promote the Transformation and Development of Resource-based Economy. http:/www.gov.cn/zhengce/content/2017-09/11/c ontent_5224274.htm.

2. Shanxi Provincial Department of Communications. (2019). Shanxi Province's Global Tourism Network Highway Planning Report. http://jtyst.shanxi.gov.cn/qgyw/165296.jhtml.

3. Ministry of Transport, Zhejiang Province. (2017). Management Information of Zhejiang Province for Building a Beautiful Economic Promenade. http://www.mot.gov.cn/.

4. Meng Qiang. (2018) Research on China's Tourism Highway Development Countermeasures Based on the Main Contradictory Views of the New Era Society. Journal of Management College of Ministry of Transport.2018(03):15-18.

5. Chen Shuiying. (2018) Government governance mechanism and quality tourism development based on multiple co-governance. Tourism Research.2018(06):2-5. 